\title{
OPTIMALISASI PEMANFAATAN PEWARNA ALAMI (NATURAL DYES) UNTUK PREPARAT MASERASI (GOSOK) TULANG
}

\author{
Dewi Puspita Sari* dan Harlita \\ Pendidikan Biologi Fakultas Keguruan dan Ilmu Pendidikan, Universitas Sebelas Maret \\ *E-mail: dewipuspita@staff.uns.ac.id
}

Diterima 2 Januari 2020, Disetujui 12 April 2020, Diterbitkan 15 Mei 2020

\begin{abstract}
A method of maceration can be used for making tissue slide wich are hard as bone, teeth, and the hard other preparation. The purpose of making maceration slide is to be identify parts bone tissue main the thigh or teeth. Benefits making maceration slide is the quality and satisfaction result from preparation and easy check microtechnique preparation about the parts of the structure of havers system. The effort to make maceration slide better quality is to apply dyesstuff. In general colourful ingredients often worn is dyestuff synthetic. Dyestuff this sometimes it is difficult to get applied in scholl because prices and the use of. Based on urgency that is, the use of a natural dye expected to be the solution. Coloring matter natural will ne used for staining among others (1)extract fruit beet (Beta vulgaris L), (2) Secang wood (Caesalpinia sappan L) 3) turmeric (Curcuma domestica Val). Method used in maceration with series of stages the sample collection, fixation, dealcoholization,staining, and ends with mounting. The research was showed that natural dye of extract fruit beet (Beta vulgaris $L$ ) and turmeric (Curcuma domestica Val) has optimalize at 15 and 30 minutes. Secang wood (Caesalpinia sappan L) has the best colour cosistency to dye bone maceration slide. The optimization of the best time is 30 and 45 minutes with dye secang wood. Turmeric and fruit beet having persisten staining tend to pale and not scattered evenly distributed on haversian system.
\end{abstract}

Keywords: Natural dyes, Maceration method, Bone,Haversian system

\section{PENDAHULUAN}

Struktur tulang merupakan bagian penting dalam perkembangan kurikulum pembelajaran anatomi. Pemahaman tentang struktur tulang sebagai bagian jaringan bersifat keras diupayakan semudah mempelajari struktur histologi dari jaringan yang bersifat lunak (Ajayi \& Edjomariegwe, 2016). Pengkoleksian preparat tulang dapat digunakan untuk kepentingan saintifik dan aktivitas pembelajaran, preparat ini mampu memberikan informasi yang spesifik dari karakter tulang pada hewan vertebrata (de Oliveira, 2018). Beberapa metode dapat diaplikasikan untuk memperoleh preparat tulang. Pertama dengan cara embedding atau paraffin method (Phadmacanty \& Kurniati, 2019), metode ini dilakukan dengan proses dekalsifikasi terlebih dahulu kemudian dilakukan pewarnaan menggunakan chemical dyes jenis hematoxylin ehrlich. Cara kedua adalah dengan maceration method atau yang dikenal dengan maserasi (Wahyuni, 2015). Preparat maserasi atau gosok merupakan preparat yang diperoleh melalui metode mikroteknik untuk pembuatan jaringan yang sifatnya keras seperti sediaan tulang dan gigi.

Metode gosok atau maserasi digunakan pada sediaan yang sulit diris (section) atau sulit memperoleh sediaan dengan ketebalan merata. Secara singkat, preparat gosok atau maserasi dilakukan dengan menggergaji tulang dan merebusnya dalam air mendidih sampai beberapa waktu, lalu potongan tulang yang kecil digosok dengan arah yang sudah ditentukan sebelumnya seperti arah serong, vertikal, dan horisontal. (Wahyuni, 2015)

Pembuatan preparat gosok tanpa proses pewarnaan baik dengan pewarna sintetik maupun alami sudah lama dilakukan dan sebagai hasilnya preparat tulang kurang begitu jelas diamati secara mikroskopis. Berbagai upaya terus dilakukan untuk meningkatkan kualitas preparat salah satu diantaranya adalah dengan menggunakan teknik pewarnaan (staining). Pewarnaan bertujuan untuk mempertajam dan (c) 2020 Florea : Jurnal Biologi dan Pembelajarannya | 31 
memperjelas elemen jaringan, terutama selselnya, sehingga dapat dibedakan dan ditelaah dengan mikroskop. Tanpa pewarnaan, penampakan jaringan akan transparan sehingga sedikit menyulitkan dalam penelaahan dengan mikroskop (Prawasti et al., 2014).

Zat warna yang digunakan harus memiliki syarat sebagai berikut: 1) senyawa organik kompleks punya pembawaan khusus (warna), 2) dapat dipertahankan dalam jaringan, 3) terdiri dari gugus kromophore (Gunarso, 1989) Zat warna alami (natural dyes) adalah zat warna yang diperoleh dari alam khususnya dari tumbuh-tumbuhan secara langsung maupun tidak langsung. Setiap tanaman dapat sebagai sumber zat warna alam karena mengandung pigmen. Potensi ini ditentukan oleh intensitas warna yang dihasilkan dan sangat tergantung kepekaannya dalam fungsinya sebagai indikator titrasi asam basa (Setiawan et al., 2016). Pewarna alami yang dikembangkan dalam penelitian adalah : buah bit (Beta vulgaris L), kulit kayu secang (Caesalpinia sappan L), dan umbi kunyit (Curcuma domestica Val).

Komponen jaringan tulang (compact bone) secara histologi tersusun atas osteon (Haversian system atau sistem Havers) adalah kompleks dari lamellae konsentris (cylindrical shaped lamellar bone) yang mengelilingi sebuah kanal pusat (kanal havers) yang berisi pembuluh darah, saraf, jaringan ikat longgar, dan endosteum. Pada lapisan yang termasuk sistem havers secara berturut- turut dari lamellae ditemukan lacunae (lakuna) yang berisi osteosit yang dihubungkan oleh canaliculi (kanalikuli) yang mengandung sel dendritik dan dihubungkan secara gap junction. Osteon menerima nutrisi dan oksigen dari kanal havers. Batas luar dari satu osteon mengandung lapisan kaya kolagen disebut cement line. Kanalis sentralis (kanal havers) mengandung $4-10$ lamela konsentris. Kanalis sentralis berkomunikasi dengan rongga sumsum tulang dan periosteum melalui perforating canals yang memanjang disebut Volkmann canals (Mescher, 2013)
Penelitian bertujuan untuk mengetahui kemampuan pewarna alami buah bit (Beta vulgaris L), kulit kayu Secang (Caesalpinia sappan L), dan umbi kunyit (Curcuma domestica Val) sebagai sebagai pewarna alternatif dalam pewarnaan preparat maserasi gosok tulang (2) untuk mengetahui kualitas pewarnaan terbaik dari dari pewarna alami buah bit (Beta vulgaris L), kulit kayu secang (Caesalpinia sappan L), dan umbi kunyit (Curcuma domestica Val) sebagai sebagai pewarna alternatif dalam pewarnaan preparat maserasi gosok tulang.

\section{METODE PENELITIAN}

Metode yang dilakukan adalah maserasi atau menggosok tulang ayam dengan arah tertentu (Wahyuni, 2015) kemudian diberi perlakuan pewarnaan dengan rentang waktu tertentu. Kegiatan penelitian dilaksanakan di laboratorium struktur dan perkembangan hewan prodi Pendidikan Biologi FKIP UNS dengan kegiatan meliputi 3 tahap: 1) tahap persiapan, meliputi pembuatan ekstrak pewarna alami untuk diaplikasikan pada preparat gosok, 2) pembuatan preparat gosok berbahan tulang femur ayam 3) pengamatan struktur histologis dari preparat maserasi. Pewarnaan dilakukan dengan memberikan perlakuan waktu yang berbeda sehingga diperoleh warna dan waktu yang optimal untuk membuat preparat yang baik,. Alat dan bahan yang digunakan adalah: Alat : Panci untuk merebus tulang femur ayam dan ekstrak kayu secang, kompor gas, lap, parut kelapa, saringan, beker glass, gergaji, amplas, Pisau buah atau cutter, botol vial kaca, pipet tetes, cover glass, object glass cekung, gelas arloji, staining jar, mikroskop merk Nikon Eclipse 80i. Bahan: Femur ayam broiler (Gallus gallus sp.), air untuk merebus, aquades, alkohol bertingkat (30\%, 50\%, $60 \%, 70 \%, 80 \%, 90 \%$ ) alkohol absolut, xylol, tisu, canada balsam, buah bit (Beta vulgaris L), kulit kayu secang (Caesalpinia sappan L), dan umbi kunyit (Curcuma domestica Val). Pembuatan ekstrak pewarna dilakukan dengan cara memarut umbi buah bit dan kunyit lalu diperas sampai diperoleh volume 
sari buah bit dan kunyit masing-masing sebanyak $50 \mathrm{ml}$. Sari kayu secang dengan menggunakan air sebanyak $100 \mathrm{ml}$, kemudian di rebus sampai tersisa $50 \mathrm{ml}$ Pembuatan preparat mengacu pada protokol sebagai berikut:

1. Menyediakan tulang bagian femur ayam broiler (Gallus gallus sp.) yang sudah disembelih dan membersihkan daging yang menempel pada tulang.

2. Merebus tulang selama \pm 1 jam hingga semua otot bersih dan mengangkatnya.

3. Memotong tulang secara membujur menggunakan gergaji sepanjang $0,5 \mathrm{~cm}$.

4. Menggosokkan potongan tulang pada amplas, sambil ditetesi air secukupnya agar tipisnya merata dan gosok berlawanan dengan arah jarum jam agar jaringan yang diamati tidak rusak.

5. Setelah tulang menipis dan bagianbagiannya sudah terlihat, tulang diletakkan di atas kaca arloji yang berisi aquades untuk membersihkan debris yang tersisa, kemudian sediakan botol vial kaca yang sudah berisi alkohol $30 \%$ dan fiksasi selama 30 menit selanjutnya direndam dengan aquades selama 2 menit.

6. Tahap selanjutnya staining, alkohol $30 \%$ di buang dan diganti pewarna alami ekstrak buah bit, kulit kayu secang, dan umbi kunyit dengan variasi waktu 15 , 30, 45, 60 menit.

7. Kemudian pewarna alami kemudian dicuci dalam air mengalir dan dilanjutkan dengan dehidrasi

8. Dehidrasi menggunakan alkohol bertingkat $30 \%$ sampai dengan absolut masing- masing selama 2 menit

9. Alkohol absolut diganti dengan xylol dan disimpan selama over night

10. Mounting: preparat yang sudah ada di dalam xilol, diambil kemudian diletakkan di object glass ditetesi Canada balsam dan ditutup dengan cover glass (gunakan tisu untuk menyerap kelebihan canada balsam)

11. Mengamati preparat : preparat diamati dengan menggunakan perbesaran lemah menuju kuat dan didokumentasikan kualitas warna dan strukturnya

Data pengamatan preparat maserasi dianalisis secara deskriptif kualitatif melalui analisis kualitas struktur histologis preparat maserasi dan kualitas warna dengan penggunaan interval waktu sehingga diperoleh data kualitas preparat yang paling optimal dari sampel histologi maserasi tulang. Hasil preparat dengan waktu terbaik serta perbandingan pewarna alami terbaik yang akan direkomendasikan sebagai pewarna alami yang dapat diaplikasikan untuk preparat gosok tulang (maserasi). Indikator kejelasan preparat mengadaptasi dari (Wahyuni, 2015) yaitu sangat jelas, jelas, dan tidak jelas serta kekontrasan preparat dengan kriteria sangat kontras, kontras, tidak kontras.

\section{HASIL DAN PEMBAHASAN}

Pembuatan preparat maserasi tulang memakai teknik menggosok tulang dengan alat penggosok berupa amplas yang memiliki permukaan halus dengan arah yang berlawanan jarum jam. Hasil yang diperoleh berupa cincin tulang tipis yang memiliki ketebalan 0,1 - 0,3 mm. Proses fiksasi, adalah menjaga supaya kondisi jaringan preparat seperti jaringan saat masih kondisi hidup (Sutikno, 2016). Staining dengan menggunakan pewarna alami bertujuan untuk memudahkan pengamatan jaringan tulang. Proses dehidrasi menggunakan alkohol bertingkat untuk menarik air dari jaringan. Dealkoholisasi dengan xylol bertujuan untuk menarik alkohol dan menggantinya dengan larutan xylol (Prawasti et al., 2014). Mounting dilakukan untuk membuat preparat. Hasil penelitian diperoleh hasil preparat sebagai berikut: 


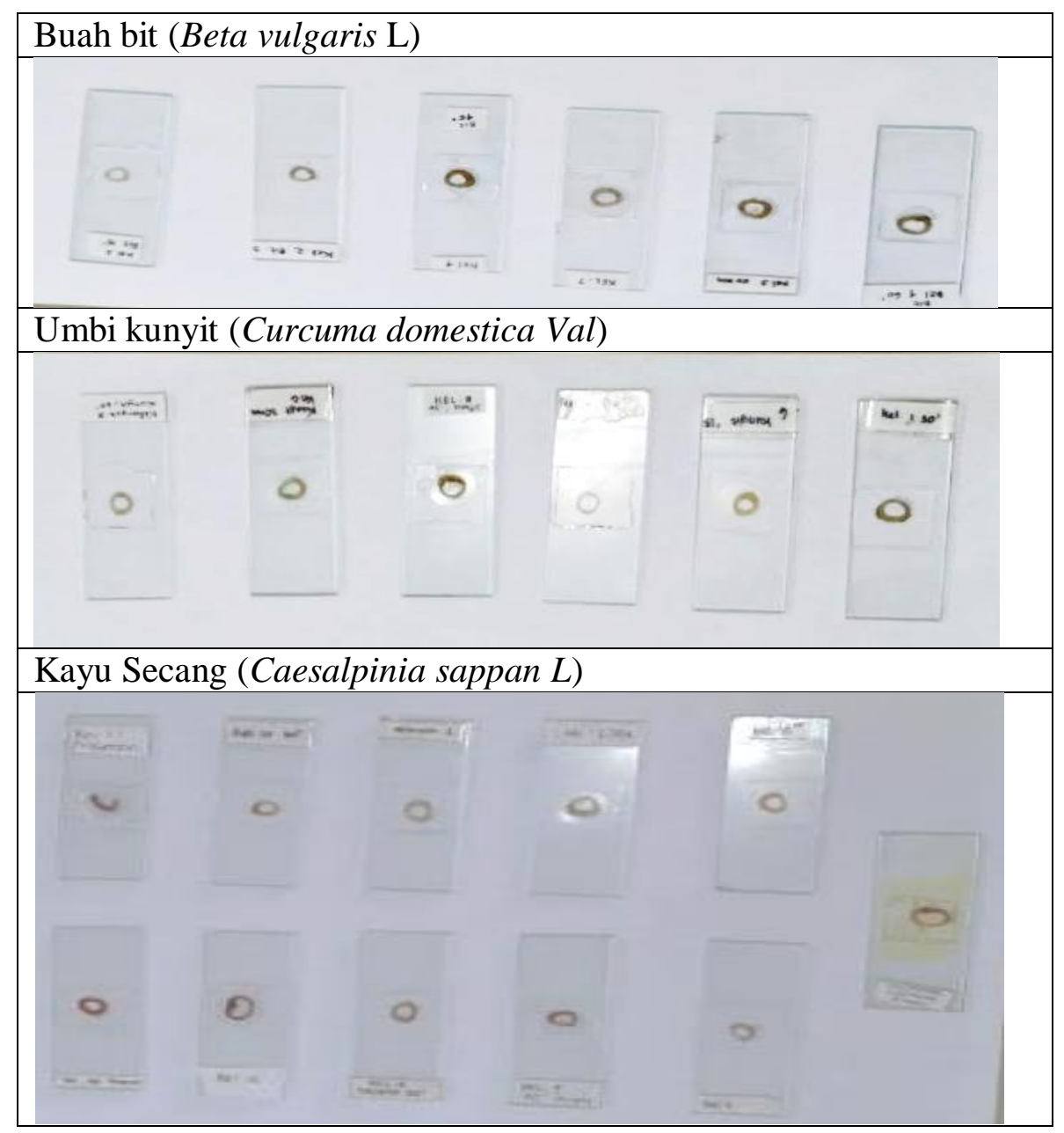

Gambar. 1. Hasil pembuatan preparat maserasi tulang Gallus gallus sp dengan menggunakan Pewarna alami dari buah bit (Beta vulgaris L), Kulit kayu secang (Caesalpinia sappan L), dan Umbi Kunyit (Curcuma domestica Val).

Teknik pembuatan preparat maserasi memiliki hasil yang beragam, kondisi ini disebabkan karena penggosokan dilakukan secara manual sehingga dijumpai preparat dengan ketebalan yang berbeda. Selain itu proses interval waktu dan pemberian larutan kimia serta karakter pewarna alami juga membawa faktor tersendiri.

Bahan yang digunakan dalam pembuatan preparasi maserasi diantaranya yaitu: Aquades digunakan untuk menghilangkan sisa-sisa larutan atau zat warna (Prawasti et al., 2014). Larutan alkohol 30\% merupakan larutan yang digunakan untuk fiksasi. Fiksasi adalah suatu usaha untuk mempertahankan elemen-elemen sel atau jaringan, mengubah indeks bias bagian-bagian sel, kemampuan untuk membuat jaringan mudah menerap zat warna sehingga bagian-bagian dalam sel tersebut mudah terlihat di bawah mikroskop,
Alkohol bertingkat $(50 \%, 60 \%, 70 \%, 80 \%$, $90 \%, 100 \%)$. Dehidrasi bertujuan untuk menarik kandungan air yang ada pada jaringan hewan. Dehidrasi alkohol bertingkat dilakukan dengan menggunakan alkohol bertingkat dari presentase rendah ke presentasi tinggi (Sutikno, 2016). Xylol, Merupakan larutan penjernih yang memiliki karakteristik berwarna jernih dan memiliki bau yang menyengat. Tujuan dari perendaman dalam xylol ini agar sel dan jaringan yang akan diamati terlihat jernih dan transparan. Fungsi utama dari xilol adalah sebagai penjernih dan medium pelarut entelan. Kanada balsam atau entelan merupakan perekat yang berfungsi untuk merekatkan bahan preparat kedalam objek glass (Wahyuni, 2015). Hasil pengamatan maserasi tulang mikroskop dengan 
menggunakan pewarna alami buah bit (Beta vulgaris L), kulit kayu secang (Caesalpinia sappan L), dan umbi Kunyit (Curcuma domestica Val). dan variasi waktu ditunjukkan pada gambar 2 .

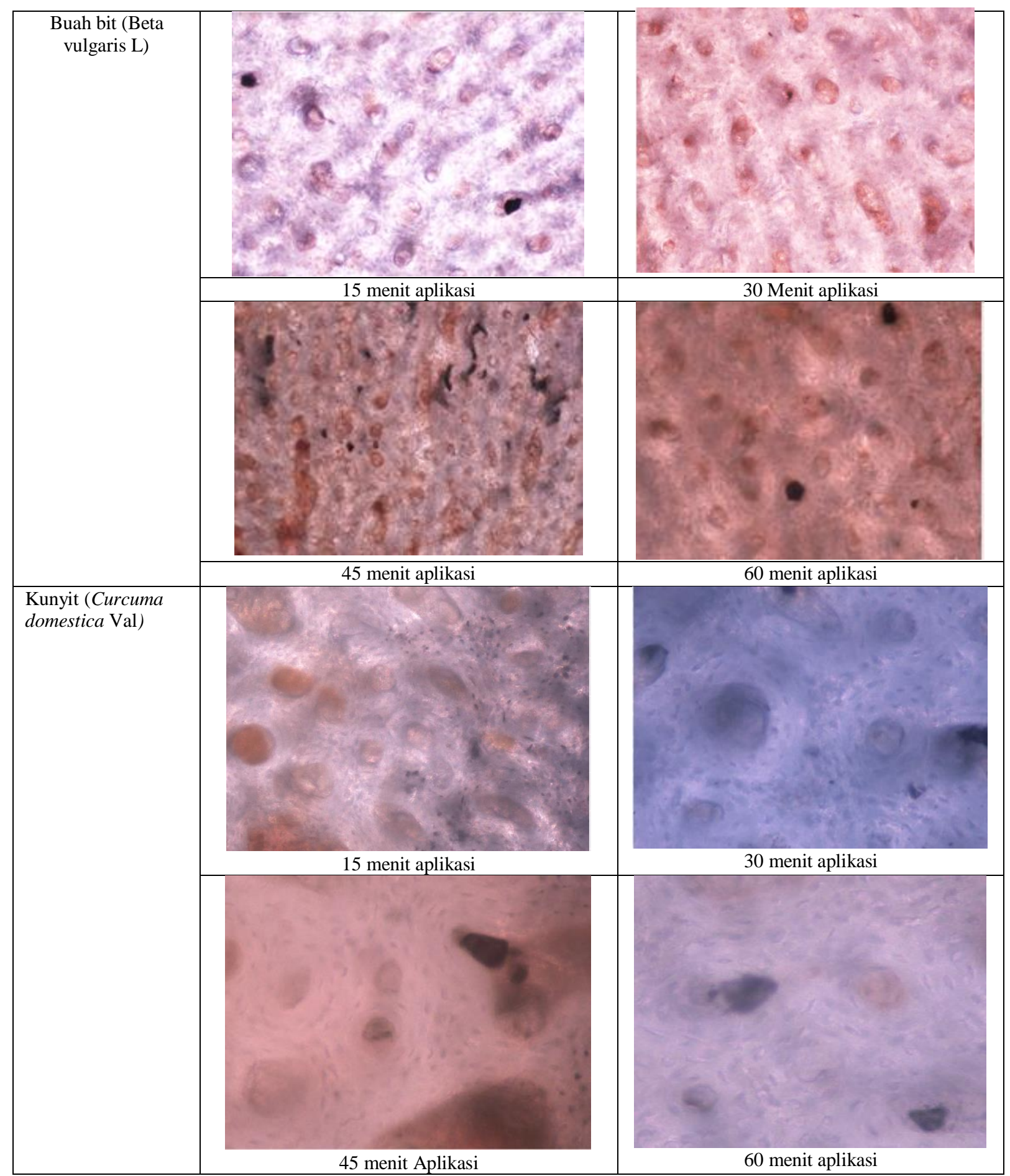




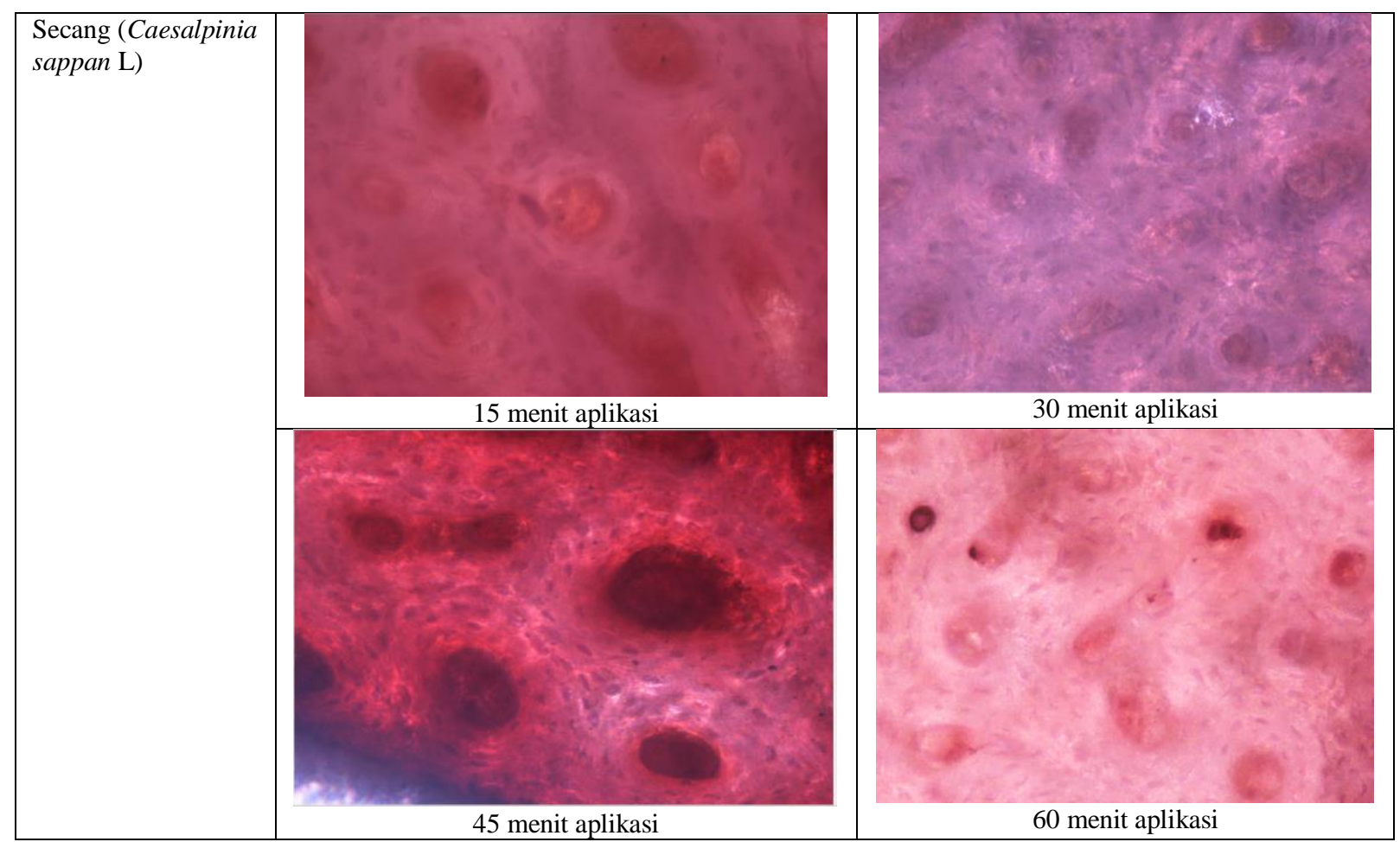

Gambar 2. Hasil preparasi maserasi tulang Pewarna alami dari buah bit (Beta vulgaris L), Umbi Kunyit (Curcuma domestica $\mathrm{Val}$ ), dan Kulit kayu secang (Caesalpinia sappan L) yang diamati dengan mikroskop perbesaran 400x

Sebagai bahan pembanding, gambar struktur jaringan tulang (compact bone) tersusun dari sistem havers. Bagian paling sentral disebut saluran havers, kemudian melingkar tersusun dari deposit kalsium yang disebut lamella. Pada diskus lamella akan ditemukan lakuna yang berisi osteosit dan dihubungkan oleh canaliculi (kanalikuli). Secara struktur histologis jaringan tulang diinterpretasikan sebagai berikut:

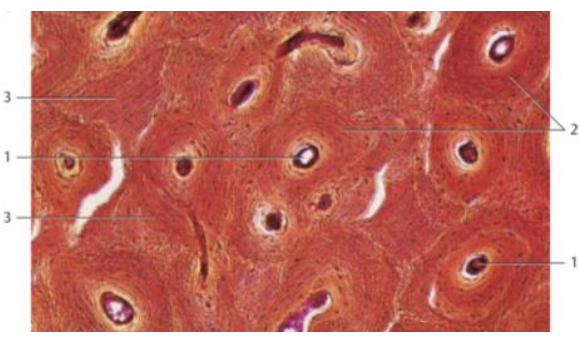

A

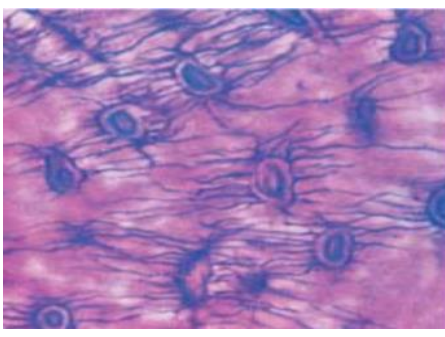

B

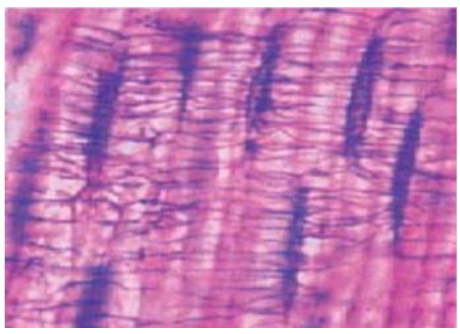

Gambar 3. Struktur histologi tulang: A. struktur tulang kompak 1.Haversian canals, vessels 2 Haversian systems, osteons 3 Interstitial lamellae. B. lacuna dan kanalikuli (tidak teramati dengan sediaan histologis biasa) sumber: (Kuehnel, 2003)

Berdasarkan hasil pengamatan preparat maserasi dengan menggunakan mikroskop diperoleh hasil semua preparat yang diwarnai dengan buah bit (Beta vulgaris L), kulit kayu secang (Caesalpinia sappan L), dan umbi kunyit (Curcuma domestica Val) menunjukkan struktur tulang yang dapat diamati dengan tingkat kejelasan preparat yang bervariasi.

\section{Buah Bit (Beta vulgaris L)}

Hasil pengamatan pada preparat Buah Bit (Beta vulgaris L) menunjukkan kualitas penggosokan yang masih kurang bagus. Struktur sulit agak diamati pada preparat dengan pewarnaan selama 45 menit. Hal ini 
terjadi karena beberapa faktor diantaranya adalah: proses menggosok yang terlalu keras dan tidak berlawanan arah jarum jam atau dilakukan secara miring sehingga tidak menampakkan struktur osteon yang bagus. Interval waktu 15, 30, dan 60 menit menunjukkan hasil yang cukup jelas dengan bagian tulang yang teramati berupa sistem havers yang terdiri dari saluran havers, lamella, lakuna. Kualitas dan kekontrasan warna masih belum optimal namun pada interval waktu 15 dan 30 menit sudah mendekati jelas dan kontras. Kondisi kurang kontras disebabkan karena perendaman yang kurang optimal dalam pewarna karena hanya dilakukan selama 15 menit dan 30 menit sehingga pigmen warna belum menyerap dengan sempurna ke dalam jaringan.

Pada bagian kanal Havers menyerap warna lebih banyak dibanding dengan bagian lainnya. Kondisi ini terjadi karena pewarna yang digunakan adalah lauratan yang fresh sedangkan teknik pewarnaan alami memerlukan suatu proses filtrasi agar merata dan mempermudah pengamatan suatu sel atau jaringan dalam pembuatan preparat gosok tulang (Gresby, 2013). Menurut (Kiernan, 2006) pewarna khusus digunakan untuk akan memberikan warna yang berbeda dari tiap sel karena sel memiliki kemampuan menyerap warna yang berbeda. Perbedaan muatan anion dan kation akan mempengaruhi struktur makromolekul dalam memunculkan intensitas dan kekontrasan warna.

Ekstrak bit (Beta vulgaris L) yang mengandung pigmen betasianin untuk memberikan warna merah pekat. Pewarna bit merah dihasilkan dari ekstrak cair bit merah yang terdiri dari berbagai macam pigmen yang semuanya termasuk dalam kelas betalain. Betalain terdiri atas dua kelompok yakni red betasianin dan yellow betaxanthin dimana kedua macam pigmen yang terkandung di dalamny memberikan kontribusi terhadap tingginya aktivitas antioksidan pada bit merah (Wibawanto et al., 2014). Ekstrak buah bit bisa menghasilkan warna karena pigmen betasianin yang terdapat pada buah bit lebih stabil (Fatmasari et al., 2017). Menurut
(Herawati, et al, 2018). Konsentrasi ekstrak buah bit yang meningkat akan menyebabkan warna merah dari betasianin juga meningkat.

Hasil yang didapatkan pada penelitian ini kurang memuaskan karena bagian-bagian struktur pada tulang kurang jelas walaupun sudah dapat diidentifikasi. Pada sediaan terlihat bagian-bagian tulang yaitu lacuna, lamela, dan kanal Havers. Kanal Havers yaitu suatu kesatuan sel-sel tulang dan matriks tulang mengelilingi suatu pembuluh darah dan saraf yang membentuk suatu system (Enlow, 1962). Pada segi warna, bagianbagian tulang sudah terwarnai sehingga terlihat lebih jelas walaupun tingkat kejelasan dan ketajaman gambar rendah. Pada preparat tampak garis dan bercak hitam yang disebabkan karena tulang tidak terendam xilol saat penyimpanan. Dengan waktu 15 dan 30 menit tampak lebih kontras dan warna lebih menyatu sehingga lebih mudah untuk mengidentifikasi bagian-bagian tulang

Beberapa faktor yang menyebabkan hasil struktur kurang jelas adalah perebusan yang tidak tepat dapat berakibat tulang masih terlalu keras sehingga sulit diiris atau terlalu lunak sehingga tulang hancur dan tidak bisa diiris, pemotongan tulang yang tidak merata dapat berpengaruh terhadap proses pengasahan dan penggosokan tulang yang juga kurang merata sehingga mengakibatkan jaringan-jaringan tulang tidak terlalu jelas dan tulang menjadi rawan patah karena memiliki tebal yang tidak merata, kurangnya ketelitian pada saat proses penggosokan mengakibatkan struktur tulang mengalami kerusakan. Selain itu, kurang tepatnya proses pembuatan larutan, konsentrasi larutan dan interval waktu pemberian pewarna pada tulang agar preparat dapat terwarnai secara optimal (Wahyuni, 2015).

\section{Kunyit (Curcuma domestica Val)}

Kunyit (Curcuma domestica Val) memiliki pigmen aktif yang dapat mewarnai jaringan atau sel yang memberikan warna kuning yang sering disebut kurkuminoid. Kurkuminoid adalah senyawa khas dari gugus fenolik yang tersusun atas antosianin kurkumin, monodesmetokurkumin, dan 
bidesmetokurkumin. Komponen yang khas dan dapat memberikan warna kuning adalah kurkumin (Sa'adiyah, 2015) Warna biru yang didapatkan saat pengamatan karena kandungan antosianin curcumin pada kunyit. Antosianin merupakan bagian dari senyawa flavonoid yang secara luas terbagi dalam polifenol. Proses pewarnaan pada jaringan muncul karena reaksi ikatan elektrostatik antara muatan ion zat warna yang bersifat asam akan melepaskan muatan positif dan bagian jaringan yang bersifat basa, sehingga jaringan dapat terwarnai. Zat warna asam akan mewarnai bagian sel yang bersifat basa dan sebaliknya, sel yang bersifat asam akan terwarnai oleh zat warna basa (Mescher, 2013). Antosianin akan berubah warna seiring perubahan $\mathrm{pH}$. Pada $\mathrm{pH}$ tinggi antosianin akan cenderung berwarna biru atau tidak berwarna, sedangkan apabila $\mathrm{pH}$ rendah berwarna merah (Wahyuni, 2015)

Pewarnaan dengan kunyit terlihat cukup kontras pada interval waktu 15 dan 30 menit. Warna kuning kurang dominan karena konsentrasi yang tidak sepekat kayu secang maupun buah bit. Aplikasi mordant sebagai kemikalia yang ditambahkan diharapkan mampu untuk mempertahankan warna dan meningkatkan afinitas sehingga terjadi ikatan kimia yang lebih permanen (Bechtold \& Mussak, 2009). Perendaman xilol yang terlalu lama (over night) menyebabkan preparat menjadi kering dan rapuh (Prawasti et al., 2014) serta menyebabkan warna menjadi luntur, sehingga perlu analisis lebih lanjut terhadap protokol penelitian. Tulang yang diwarnai selama 45 menit mengalami kendala pada hilangnya pewarna kunyit karena direndam dalam xilol, warna pada tulang berubah dari kuning menjadi keabuan. Ketidak kontrasan pada preparat yang dibuat dikarenakan afinitas kimia yang lemah dan preparat yang kurang optimal dalam menggosok.

\section{Kayu Secang (Caesalpinia sappan L)}

Kulit kayu dan akar dari Secang menghasilkan warna merah tua, yang diproduksi oleh senyawa brazilin, protosappanins, sappan chalcone dan haematoxylum (Bechtold \& Mussak, 2009). Selain sebagai pewarna alami, secang juga memiliki antioksidan dan antimikroba. Warna merah yang tua akan muncul saat kayu secang dilarutkan ke dalam pelarut yang cocok. Pelarut yang digunakan antara lain air, etanol, dan methanol (Kusumawati \& Kistyanto, 2019). Kayu secang (Caesalpinia sappan L) mengandung pigmen, tanin, brazilin, asam tanat, resin, resorsin, brazilin, sappanin, dan asam galat. Dari komponen tersebut yang paling menarik adalah zat warnanya. Pigmen brazilin memiliki warna merah tajam dan cerah pada $\mathrm{pH}$ netral $(\mathrm{pH}=$ 6-7) dan bergeser ke arah merah keunguan dengan semakin meningkatnya $\mathrm{pH}$. Pada $\mathrm{pH}$ rendah $(\mathrm{pH}=2-5)$ brazilin akan memiliki warna kuning (Fardhyanti, 2015).

Berdasarkan hasil pengamatan pada preparat tulang, terjadi perbedaan antara preparat pewarna secang dengan waktu 15 menit dan 30 menit. Pada preparat dengan pewarna 15 menit sel-sel tulang nampak berwarna merah pekat sedangkan pada preparat dengan pewarna 30 menit sel-sel tulang nampak berwarna merah keunguan. Bagian-bagian dari osteon lebih terlihat jelas pada preparat dengan pewarna 15 menit daripada pewarna 30 menit. Kekontrasan warna yang nampak lebih tajam pada pewarna 30 menit. dari kedua preparat dapat diidentifikasi bagian-bagian dari tulang seperti, lakuna, kanal havers, lamela, dan osteon. Pada preparat dengan waktu 30 menit dijumpai batas antar osteon kurang jelas. Kanalikuli tidak dapat diidentifikasi karena bagian ini tidak akan nampak dengan pembuatan sediaan konvensional (Ovalle, 2013). Beberapa bagian jaringan tulang berupa kanal havers (saluran havers), lakuna dengan pewarnaan selama 45 menit dan 60 menit. Terjadi kekontrasan warna antara 2 interval waktu, pada aplikasi 45 menit intensitas warna yang dihasilkan terlalu dalam dan pekat, namun pada aplikasi 60 menit justru sebaliknya lebih pucat dan soft. Hasil yang bervariasi dari intensitas dan kontras pewarna alami disebabkan oleh tingkat kestabilan terhadap panas, cahaya, 
dan tingkat keasaman yang tidak menentu walaupun relatif aman (Sa'adiyah, 2015)

Hasil yang kurang optimal dikarenakan pada proses penggosokan tulang kurang tipis dan arah gosokan tulang tidak sama sehingga preparat yang dihasilkan kurang begitu jelas dan tidak menampakkan semua bagian-bagian dari tulang. Struktur tulang ada yang tersimpan dalam xylol terlalu lama, padahal xylol murni tersebut berfungsi untuk menjernihkan jaringan (clearing agent), sehingga jaringan menjadi pucat, warna hilang, kering, dan rapuh yang justru membuat sediaan yang telah jadi tidak bertahan lama (Wahyuni, 2015).

\section{KESIMPULAN}

1. hasil metode gosok dengan menggunakan pewarnaan ekstrak pewarna alami, semua pewarna alami yaitu buah bit (Beta vulgaris L), kulit kayu secang (Caesalpinia sappan L), dan umbi kunyit (Curcuma Berdasarkan hasil penelitian didapatkan domestica $\mathrm{Val}$ ) mampu mewarnai preparat maserasi tulang

2. Kualitas pewarnaan tergantung pada proses penggosokan tulang dan afinitas zat warna pada jaringan tulang. Struktur tulang dapat diamati dengan tingkat kualitas dan kekontrasan warna yang bervariasi. Pada preparat yang diwarnai dengan ekstrak buah bit dan umbi kunyit optimal pada interval waktu 15 dan 30 menit, serta secang pada interval waktu 15 dan 45 menit dengan ciri pewarnaanya lebih merata, kekontrasan lebih tinggi dan struktur yang dapat teramati berupa kanal havers, lamella, dan lakuna.

\section{UCAPAN TERIMA KASIH}

Terimakasih kepada LPPM UNS atas kesempatan melakukan penelitian skim Mandiri Aktif dengan judul "Optimalisasi pemanfaatan pewarna alami (natural dyes) untuk preparat maserasi (gosok) tulang".

\section{DAFTAR PUSTAKA}

Ajayi, A., \& Edjomariegwe, O. (2016). A Review of Bone Preparation Techniques for Anatomical Studies. Malaya Journal of
Biosciences, 3(2), 76-80.

Bechtold, T., \& Mussak, R. (2009). Handbook of Natural Colorants. In Handbook of Natural Colorants. https://doi.org/10.1002/9780470744970

de Oliveira, M. B. (2018). Methods of biological maceration in the preparation of bat skulls: Benefits and limitations. Papeis Avulsos de Zoologia, $\quad 58, \quad 0-4$. https://doi.org/10.11606/18070205/2018.58 .44

Enlow, D. H. (1962). Functions of the Haversian System. Department of Anatomy,The University of Michigan,Ann Arbor,Michigan, 269-305.

Fardhyanti, D. ; R. D. R. (2015). Pemungutan Brazilin dari Kayu Secang (Caesalpinia sappan L) dengan Metode Maserasi dan Aplikasinya untuk Pewarnaan Kain. Jurnal Bahan Alam Terbarukan, 4(1), 8-17. https://doi.org/10.15294/jbat.v4i1.3768

Fatmasari, D., Supriyana, \& Sukmawati. (2017). Larutan Ubi Jalar Ungu Dan Buah Bit Sebagai Bahan Identifikasi Keberadaan Plak Gigi. Jurnal Kesehatan Gigi, 04(1), 19-24.

Gresby, A. (2013). Pemanfaatan Filtrat Daun Jati Muda (Tectona grandis) Sebagai Bahan Pewarna Alternatif Pembuatan Preparat Maserasi Batang Cincau Rambat (Cyclea barbata). Universitas Muhammadiyah Malang.

Gunarso, W. (1989). Bahan Pengajaran Mikroteknik. Departemen Pendidikan dan Kebudayaan Direktorat Jendral Pendidikan Tinggi Pusat Antar Universitas Ilmu Hayat IPB.

Herawati, Ervika R N,Dini Ariani,Miftakhussolikhah,Fela Laila, Y. P. (2018). Karakteristik Sohun Pati Aren Kentang Hitam Dengan Penambahan Ekstrak Umbi Bit, Daun Suji, Dan Kunyit. Jurnal Penelitian Pasca Panen, 14(3), 147155.

Kiernan, J. A. (2006). Dyes and other colorants in microtechnique and biomedical research. Coloration Technology, 122(1), 1-21. https://doi.org/10.1111/j.14784408.2006.00009.x

Kuehnel, W. (2003). Color Atlas of Cytology, Histology and Microscopic Anatomy (Thieme Flexibook) (4th editio). Thieme. http://www.amazon.com/CytologyHistology-Microscopic-Anatomy- 
Flexibook/dp/1588901750

Kusumawati, N., \& Kistyanto, A. (2019). Combination of Caesalpinia sappan and Leucaena leucocephala L . Leaves . National Seminar of Chemistry, 1 (Atlantis press), 33-37.

Mescher, A. L. (2013). Junqueira's Basic Histology (13th Edition). McGraw-hill Education.

Ovalle, W. K. (2013). Essential Histology. Saunder, 2nd Edition.

Phadmacanty, N. L. P. R., \& Kurniati, H. (2019). Determination of the age of the paddy field frog, Fejervarya cancrivora (Anura: Dicroglossidae) by using skeletochronology. Biodiversitas, 20(9), 2739-2743. https://doi.org/10.13057/biodiv/d2009xx

Prawasti, T. S., Sulistyaningsih, Y. C., Dorly, Juliandi, B., \& Juliarni. (2014). Penuntun Praktikum Mikroteknik. 2.

Sa'adiyah, R. A. (2015). Penggunaan Filtrat Kunyit (Curcuma domestica val.) sebagai Pewarna Alternatif Jaringan Tumbuhan pada Tanaman Melinjo (Gnetum gnemon). Berkala Ilmiah Pendidikan Biologi, 4(1), 765-769.

http://ejournal.unesa.ac.id/index.php/bioed $\mathrm{u}$

Setiawan, M. A. W., Nugroho, E. K., \& Lestario, L. N. (2016). Ekstraksi Betasianin dari Kulit Umbi Bit (Beta vulgaris) Sebagai Pewarna Alami. Agric Jurnal Ilmu Pertanian, 27(1), 38.

https://doi.org/10.24246/agric.2015.v27.i1. p38-43

Sutikno. (2016). Buku Panduan Mikroteknik Tumbuhan. Laboratorium Struktur dan Perkembangan tumbuhan Universitas Gadjah mada.

Wahyuni, S. (2015). Identifikasi Preparat Gosok Tulang (Bone) Berdasatkan Teknik Pewarnaan. Prosiding Seminar Nasional Pendidikan Biologi 2015, Prodi Pendidikan Biologi FKIP Universitas Muhammadiyah Malang, 657-666.

Wibawanto, N. R., Ananingsih, V. K., \& Pratiwi, R. (2014). Produksi Serbuk Pewarna Alami Bit Merah (Beta vulgaris L.) Dengan Metode Oven Drying. Prosiding SNST Ke5 Fakultas Teknik Universitas Wahid Hasyim Semarang, 38-43. 